\title{
Population Briefs, Vol. 9, no. 1
}

Population Council

Follow this and additional works at: https://knowledgecommons.popcouncil.org/ series_newsletters_popbriefs How does access to this work benefit you? Let us know!

\section{Recommended Citation}

Population Briefs 9(1): New York: Population Council, 2003. 


\section{IN THIS ISSUE}

- Aging

- Study Design

- Transitions to Adulthood

- Biomedical Research

- Demography

\section{The HIV/AIDS}

\section{Operations Research}

Handbook guides

program managers

through each step

in the design,

implementation,

and assessment of

HIV/AIDS programs.

see page 2

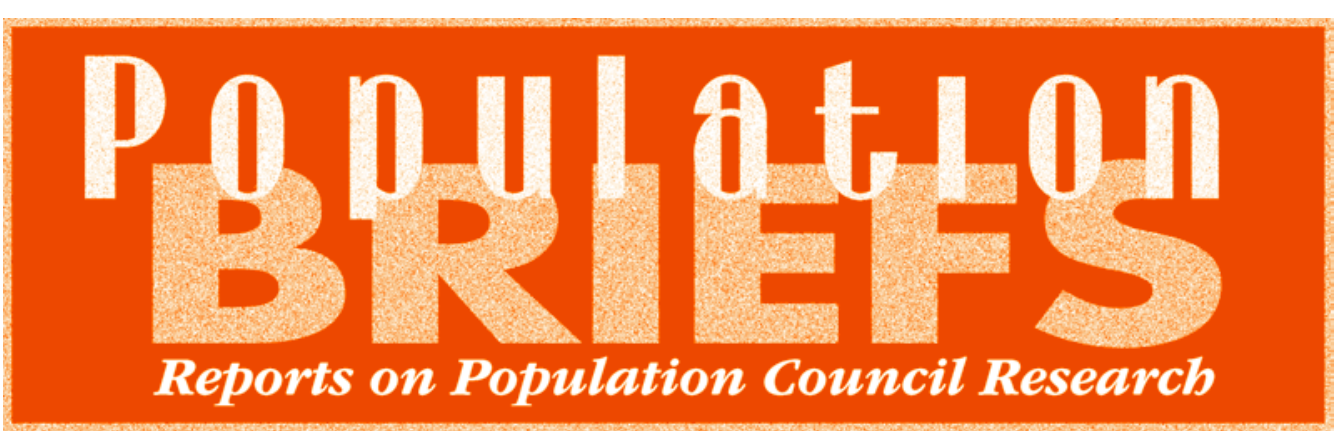

February 2003

Volume 9, Number 1

\section{Trends in Disability and Functioning Among Older Adults in the United States and Taiwan}

Rapid and widespread population aging is one of the foremost demographic phenomena of the twenty-first century. The substantial increase in the proportion of the population that is older is occurring not only in rich countries but also in the poorer countries that have recently undergone rapid fertility and mortality declines. A fundamental question surrounding the increase in survival is whether the extra years of life are being spent in good or bad health.

Older adults are more likely to use health services and to require assistance conducting daily tasks than are younger people. But in many countries they also represent an untapped resource as potential workers. Accordingly, determining the prevalence of physical limitations among the elderly is essential for forecasting both their long-term needs and the feasibility of efforts to extend their engagement in the labor force.

The direction of trends in health of the elderly is being actively researched in the United States, and some results are quite positive. Recently Population Council president Linda Martin, Vicki A. Freedman of the Polisher Research Institute, and Robert F. Schoeni of the University of Michigan published a systematic review of the evidence on improved functioning of older Americans.

At the same time, Council sociologist Zachary Zimmer, Martin, and the former director-general of Taiwan's Bureau of Health Promotion, Ming-Cheng Chang, have been investigating the question for one of the first times in an Asian nation, namely Taiwan. Asia, and Taiwan in particular, are aging even more rapidly than the West, so the answer has important policy implications there too. However, the researchers conclude that Taiwan does not appear to have been experiencing the same improvement in late-life health as has been occurring in the United States.

\section{Aging in the United States}

Over the last decade more than a dozen studies based on eight national surveys in the U.S. have assessed trends in the prevalence of self-rated oldage disability and physical, cognitive, and sensory limitations. Despite the importance of this work, the results previously had not been synthesized and critically reviewed. Freedman, Martin, and Schoeni evaluated the quality, quantity, and consistency of the recent evidence on U.S. trends and whether the trends were widespread across the population according to sex, race, and education.

"The greatest improvements appear to have occurred in the ability to carry out so-called instrumental activities of daily living, such as household chores and shopping," says Martin. These abilities were measured in four of the surveys. For example, analysis of the National Health Interview Survey found that the proportion of people ages 70 and

continued on page 6 


\section{New Operations Research Handbook Targets HIV/AIDS}

As the impact of the HIV/AIDS epidemic increases, but resources to fight it remain limited, it becomes ever more important to develop cost-effective programs to prevent, treat, and mitigate its effects. To address these needs, Population Council public health and operations research experts Andrew A. Fisher and James R. Foreit have coauthored Designing HIV/AIDS Intervention Studies: An Operations Research Handbook. The book, written for program administrators and researchers, is a step-by-step guide to creating operations research projects that could yield improved HIV/AIDS programs.

Fisher is director of the Population Council's Horizons program, which conducts research into ways of preventing the spread of HIV/AIDS, for example with services to prevent mother-to-child transmission, and mitigating its impact on individuals and communities, for example with programs to help AIDS orphans. Foreit is a senior program associate with the Council's Frontiers in Reproductive Health program, which seeks methods of improving the delivery of family planning and reproductive health services in developing countries.

\section{What is operations research?}

Operations research focuses on the day-to-day activities, or operations, of programs. Because these operations are under managerial control, it is possible for program administrators to make substantive improvements based on research findings. In the context of health service delivery, the goal of operations research is to increase the efficiency, effectiveness, and quality of services delivered by providers, and the availability, accessibility, and acceptability of services desired by users. Operations research is a continuous process with five basic steps: problem identification and diagnosis, strategy selection, strategy testing and evaluation, information dissemination, and information utilization. Findings from operations research studies can be used to improve or expand existing programs as well as to develop new approaches.

"HIV/AIDS programs are complex because the disease is complex," say Fisher and Foreit.
HIV/AIDS affects all aspects of human societyfrom the cultural sphere to the religious, politi$\mathrm{cal}$, and economic spheres. The infected and affected are many in number, diverse in nature, and widely dispersed throughout the world. HIV/AIDS programs typically address such issues as poverty, economic development, gender inequality, stigma, and discrimination. To be effective, such programs require not only community involvement and dedicated personnel, but also detailed planning at all levels, close coordination of program implementation efforts, careful training and supervision of personnel, and continuous evaluation of program development and effects. "Operations research is

\section{"HIV/AIDS programs}

are complex because

the disease is complex."

a critically important way to support and inform these essential planning, coordinating, and evaluation functions," write Fisher and Foreit.

\section{Types of operations research}

There are four basic types of operations research: exploratory/diagnostic, field intervention, evaluation, and cost-effectiveness. Exploratory/diagnostic studies seek to determine the factors responsible for a problem before a program begins. For example, if a discrepancy in rates of HIV infection were noted between villages in a small geographic area, an exploratory/diagnostic study would shed light on the factors responsible for this variation. With this knowledge, appropriate programs can be designed.

Field intervention studies test new approaches or solutions to problems in existing programs. In the example given above, researchers might have found that in the villages with low HIV prevalence, influential local leaders supported sexual behavior change, such as reducing the number of sexual partners or delaying the initiation of sexual relations, and condom distribution programs. Field intervention studies would test different ways of replicating that situation in the villages with higher HIV prevalence in order to determine the most effective strategy.

Once the most appropriate strategy was implemented, evaluation studies would confirm the success of the program. These studies can also be used to assess the achievements of interventions that have not been examined previously. In the effort to respond quickly to the devastating epidemic, HIV/AIDS programs sometimes are hastily planned and rapidly implemented. Evaluation is an ongoing process that should occur over the life of a program and could help to improve existing programs.

Finally, although the overall results of a program - in terms of increasing knowledge about HIV, changing unsafe sex practices, or reducing HIV transmission-may be known, its cost and particularly its cost-effectiveness often are not known. For program managers who have to make difficult decisions about allocating scarce resources, cost-effectiveness studies can be valuable management tools, and cost-effectiveness analyses are frequently part of intervention and evaluation studies.

The HIV/AIDS Operations Research Handbook guides program managers and researchers through each step in the design, implementation, and assessment of HIV/AIDS programs, giving them crucial tools and information in a straightforward format. To order the handbook, e-mail horizons@pcdc.org or call Jessica Nicholaides at +1-202-237-9400. The handbook can be downloaded at: http:// www.popcouncil.org/horizons/orhivaidshndbk. $\mathrm{html} \mathbf{n}$

\section{SOURCE}

Fisher, Andrew A. and James R. Foreit with John Laing John Stoeckel, and John Townsend. 2002. Designing HIV/AIDS Intervention Studies: An Operations Research Handbook. Washington, DC: Population Council.

OUTSIDE FUNDING

United States Agency for International Development 


\section{Adolescent Behavior in the Context of AIDS in South Africa}

South Africa is one of the countries hardest hit by HIV. Nearly 25 percent of the women who obtain antenatal care in South Africa are infected with HIV; in the country's most populous province, KwaZulu-Natal, the figure is 34 percent. Risky sexual behavior among youth is common; more than 35 percent of 19-yearold South African girls have been pregnant at least once.

The "Transitions to Adulthood in the Context of AIDS in South Africa" study investigates factors that may influence the lives and sexual behavior of young people in KwaZuluNatal. This longitudinal study is a collaboration among the Population Council, Tulane University, the University of Natal-Durban, and Development Research Africa (a South African research organization). The working papers discussed in this article analyze evidence from the first round of data collection.

\section{Opportunities for adolescents}

Researchers assessed the association between risk-taking behavior and opportunities for schooling, work, and other activities. They looked at information collected from a representative sample of 2,992 young people aged 14-22 years who live in Durban Metro and Mtunzini Districts of KwaZulu-Natal Province. The population of KwaZulu-Natal comprises four main population groups: African (80 percent), Indian (10 percent), white (7 percent), and a population group of mixed ancestry known as coloured (3 percent).

This study revealed that gender is far more important than population group in predicting adolescent risk taking. For example, girls who live in communities where there is a high level of sports activity or who live where schooling is easily obtained tended to report that they had not had sex in the past year. These factors do not significantly influence whether boys reported having had sex in the past year.

One factor, the prospect of employment, was correlated with less risk-taking behavior among both boys and girls. Girls in areas where earning potential was high were almost two and a half times more likely to report having used a condom the last time they had sex than were girls living in communities where fewer adolescents were working. Boys from higher-wage communities were about 50 percent more likely to report having used a condom the last time they had sex than were boys from lower-wage areas.

"This is an area that deserves more research," says former Population Council research associate Carol E. Kaufman. "Because this analysis was based on a single round of data collection, it is not possible to determine cause-and-effect relationships. However, it's possible that when young people have more opportunities for education or work, they may be more likely to forgo sexual activity or to engage in safer sex practices when they do have sex." Kaufman, now at the University of Colorado, is a Council consultant.

\section{Attitudes toward pregnancy}

In communities where early age of childbearing is common and HIV prevalence is high, adolescent boys and girls may place themselves at risk of HIV to realize their childbearing preferences. Researchers wondered whether adolescents' attitudes toward pregnancy were affected by perceptions of the risk of HIV transmission in their communities and among their peers. Investigators used evidence gathered during the first round of data collection from 1,426 sexually active young people. They found that boys were more concerned about how having a child would affect their opportunities for schooling, job training, and personal development than they were about the fact that unprotected sex might expose them to HIV. But where adults expressed concern about HIV risk among adolescents, boys reported an increased desire to avoid parenthood.

Among girls, the higher the level of school enrollment in their community, the more likely they were to want to delay pregnancy. African girls were more than three times as likely as white or Indian girls to say pregnancy would be a big problem. Even after controlling for income, girls' childbearing preferences were significantly correlated with the perceived risk of HIV infection among their peers.

"It appears that for some adolescentsand for girls more than boys - the danger of HIV infection is becoming part of the calculus as they determine the desirability of becoming parents," says Naomi Rutenberg, senior program associate with the Population Council's Horizons program. Research under the Horizons program attempts to determine the types of interventions that work to prevent HIV transmission, deliver care and support, and reduce the suffering caused by AIDS.

Although it is not possible to determine cause-and-effect relationships from this research, the data highlight points of opportunity for interventions. Programs focusing on increasing livelihood opportunities for boys and girls could be important in encouraging safer sex practices - for example, abstinence, being faithful, and condom use. Programs that assist adolescents in making an accurate assessment of their HIV risk would also be beneficial. Analyses comparing the first and second rounds of data collection are expected in mid-2003.

\footnotetext{
SOURCES

Kaufman, Carol E., Shelley Clark, Ntsiki Manzini, and Julian May. 2002. "How community structures of time and opportunity shape adolescent sexual behavior in South Africa," Policy Research Division Working Paper no. 159. New York: Population Council.

Rutenberg, Naomi, Carol E. Kaufman, Kate Macintyre, Lisanne Brown, and Ali Karim. 2002. "Pregnant or positive: Adolescent childbearing and HIV risk in South Africa," Policy Research Division Working Paper no. 162. New York: Population Council.

\section{OUTSIDE FUNDING}

The Andrew W. Mellon Foundation, the Rockefeller Foundation, the United Kingdom Department for International Development, and the United States Agency for International Development (through the Population Council's Programmatic Cooperative Agreement, the Council's Horizons program, the Focus on Young Adults project, and the MEASUREEvaluation project)

USAID-funded Horizons research is conducted in collaboration with the International Center for Research on Women, the International HIV/AIDS Alliance, the Program for Appropriate Technology in Health, Tulane University, Johns Hopkins University, and Family Health International.
} 


\section{Mirena ${ }^{\circledR}$-Induced Drop in Menstrual Bleeding Studied}

Researchers have known for years that the contraceptive Mirena ${ }^{\circledR}$ drastically reduces the excessive menstrual bleeding experienced by some women with uterine fibroids, the most common benign uterine tumors. They did not know for certain, however, what molecular mechanism accounted for this marked improvement in symptoms. Recent studies have begun to provide insight into this mystery.

Mirena, a progestin-releasing intrauterine system (IUS), was co-developed and tested by the Population Council, its International Committee for Contraception Research, and the pharmaceutical company Leiras. Mirena is now approved for use in more than 80 countries and is being used by more than 2 million women. Mirena is an extremely effective contraceptive, with fewer than 1 in 100 women becoming pregnant during five years of using the device. Berlex Laboratories, Inc., the U.S. subsidiary of Schering AG, Germany, markets Mirena in the United States under a license from the Council. Schering AG markets Mirena globally.

\section{Severe symptoms}

Women with uterine fibroids and adenomyosis of the uterus (growth of the lining of the uterus, or endometrium, into the uterine muscle) often suffer from excessive menstrual bleeding. Extreme menstrual bleeding, also known as menorrhagia, often interferes with daily activities and can leave sufferers anemic. One treatment for menorrhagia has been therapy with gonadotropin-releasing hormone $(\mathrm{GnRH})$ agonists, which induce a reversible menopause-like state. GnRH agonists, however, can have severe side effects, such as osteoporosis and hot flashes. Another common treatment, hysterectomy, leaves women permanently infertile. "Mirena offers a safe, nonsurgical alternative for the management of excessive menstrual bleeding that also preserves women's fertility," says Elof D.B. Johansson, director of the Population Council's Center for Biomedical Research.
Previous investigators have shown that in women who use Mirena, the endometrium thins. This thinning reduces the material, including blood, that is shed through menstruation. Obstetrician and gynecologist Takeshi Maruo of Kobe University collaborated with Johansson, Council researcher Irving M. Spitz, and others to determine the underlying molecular cause of changes in the endometrium of women using Mirena. Maruo is a member of the Council's International Committee for Contraception Research. The researchers examined cellular changes in the endometrium, analyzing samples taken from 15 women before and three months after the insertion of the Mirena IUS.

\section{Excessive menstrual}

bleeding can leave

sufferers anemic.

\section{Radical transformation}

In mammals, including humans, the endometrium is regulated in part by genetically programmed cell death, also known as apoptosis. The endometrium goes through a radical transformation during each menstrual cycle, which can be divided into three parts: the proliferative phase, the secretory phase, and the menstrual phase. During the proliferative phase, which starts at the end of menstrual bleeding and lasts until ovulation, increasing levels of estrogen induce the endometrium to thicken. During the secretory phase, which ranges from ovulation until the start of menstrual bleeding, the hormone progesterone causes endometrial glands to secrete mucus and other substances that would help sustain a pregnancy. If pregnancy does not occur, however, estrogen and progesterone levels drop and mass cell death begins in the endometrium.
During the menstrual phase, the uterus sheds the endometrium. "Apoptosis helps refresh the endometrium, readying it for growth during the next cycle," explains Maruo.

The researchers looked at four factors related to apoptosis in the endometrium. PCNA, a marker of cell proliferation, was less abundant in the endometrium three months after IUS insertion than it was before insertion. Bcl-2 protein, which is known to prevent apoptosis, was present in endometrial glands before the insertion of Mirena, but became scanty three months after insertion. Conversely, Fas antigen, which promotes apoptosis, was scarcely apparent before Mirena insertion, but three months after insertion Fas antigen expression became predominant in the endometrium. Finally, the number of cells observed to be undergoing apoptosis in the endometrium was greater three months after IUS insertion than it had been prior to insertion.

"The increased apoptosis in the endometrium after Mirena insertion, which we detected using multiple measures, may represent an underlying molecular mechanism that causes the endometrium to atrophy," says Maruo. "This in turn leads to improved management of menorrhagia.'

\section{SOURCES}

Laoag-Fernandez, J.B., T. Maruo, P. Pakarinen, I.M. Spitz, and E. Johansson. "Effects of levonorgestrelreleasing intrauterine system on the expression of vascular endothelial growth factor and adrenomedullin in the endometrium," Human Reproduction (in press).

Maruo, T., J.B. Laoag-Fernandez, H. Matsuo, T. Samoto, O. Kurachi, S. Takeuchi, I.M. Spitz, P. Pakarinen, P. Lähteenmäki, and E. Johansson. 2002. "Effects of levonorgestrel-releasing intrauterine system on the endometrium and the relevance to the management of menorrhagia caused by uterine myoma and adenomyosis," in T. Maruo, D. Barlow, H. Marndon, and S. Kennedy (eds.), Cell and Molecular Biology of Endometrium in Health and Disease. Osaka: Soeisha, pp. 193-207.

Maruo, T., J.B. Laoag-Fernandez, P. Pakarinen, H. Murakoshi, I.M. Spitz, and E. Johansson. 2001.

"Effects of the levonorgestrel-releasing intrauterine system on proliferation and apoptosis in the endometrium," Human Reproduction 16: 2103-2108. 


\section{End to Childbearing Delays Could Lead to Fertility Rise}

With at historic lor among demographers and policymakers: How low will it go? A study by demographer John Bongaarts, a Population Council vice president, tackles this question by analyzing the implications of changes in the timing of childbearing. The study concludes that fertility in many developed countries, especially those in the European Union, could soon rise somewhat.

Although fertility in the developed countries is low, Bongaarts believes that women's eventual childbearing levels will not be as low as the total fertility rate might suggest. This is due to a "postponement effect," which is the result of women delaying childbearing until later in life.

\section{Low fertility}

By the late 1990s, the conventionally measured fertility rate in the "more developed" world (Europe, North America, Japan, Australia, and New Zealand) had decreased to 1.6 births per woman - well below the level at which population size stabilizes, 2.1 births per woman. Low fertility may lead to extreme population aging, financial pressure on social security systems, and declining population size.

Fertility is usually measured as the total fertility rate (TFR), which equals the average number of births a woman would have if she were to bear children in each year of her life at the same rate as did women of that age in the year the TFR is calculated. It differs from the completed fertility rate (CFR), which is a longitudinal measure of the average number of children 50-year-old women in fact had. The CFR shows actual childbearing, but can only be determined after childbearing is complete. Although the CFR is more accurate, demographers prefer to use the TFR because it provides more up-to-date information on current trends in fertility.

Unfortunately, the total fertility rate can give a distorted view of fertility levels because it has been temporarily depressed by a rise in women's mean age at childbearing. In effect, when successive cohorts of women delay childbearing, births are spread out over a longer period than would be the case if they bore children at earlier ages. This effect renders the conventionally measured TFR difficult to interpret. (Conversely, if successive cohorts of women gave birth earlier than women had in the past, these births would accumulate more rapidly and thus temporarily inflate the TFR.)

\section{"The concept of}

replacement fertility is

\section{a theoretical threshold}

that bas little or no

direct meaning for

individual couples

building their families."

"The postponement effect has been present in many developed countries since the 1970s, but this distortion is temporary," Bongaarts notes. Once women who have delayed childbearing begin to have children, the downward trend in the total fertility rate could end, and a slight upturn is a distinct possibility.

\section{Second demographic transition}

These recent trends in childbearing are part of a larger process of social and demographic change usually referred to as the second demographic transition. In addition to declines in fertility, this transition is typically accompanied by widespread changes in attitudes and behaviors regarding sexuality, contraception, cohabi- tation, marriage, divorce, and extramarital childbearing.

\section{Ideal family size}

Surveys have shown that in the developed world, women on average want about two children. "In an ideal world, women would bear the number of children they want, but this clearly is not the case in contemporary developed countries," says Bongaarts. Many obstacles keep them from having the number of children they would like. These obstacles include divorce, celibacy, infertility, and the difficulties women face in combining childrearing with their educations and careers. Although analysts do not agree on which of these factors are most important in determining fertility trends, they acknowledge that these obstacles cause fertility to be lower than ideal family size.

A common past view among demographers was that fertility would level off at or near the replacement level of 2.1 births per woman. This is now seen as ill-founded and indefensible, Bongaarts notes. "The concept of replacement fertility is a theoretical threshold that has little or no direct meaning for individual couples building their families," he says.

Nevertheless, countries with very low fertility resulting from delayed childbearing could well experience modest rises in fertility in the near future if the timing of childbearing stabilizes. "But even if this happens," Bongaarts concludes, "it seems unlikely that fertility will climb back to the replacement level, because of obstacles to the implementation of fertility preferences.'

\section{SOURCE}

Bongaarts, John. 2002. "The end of the fertility transition in the developed world," Population and Development Review 28(3): 419-443.

\section{OUTSIDE FUNDING}

The William and Flora Hewlett Foundation, the Andrew W. Mellon Foundation, and the United States Agency for International Development 
older who needed help with such activities declined from 14.5 percent in 1982 to 10.9 percent in 1996.

Less clear is the evidence for trends in activities of daily living, such as bathing and feeding oneself. Difficulties with these activities are concentrated among the most severely disabled. Some surveys indicated that difficulties had become less common, while others suggested they had become more common. Evidence regarding trends in limitations in cognition and such basic physical tasks as walking and climbing showed consistent declines in prevalence, but only one or two surveys assessed each of these measures, so the evidence base is thin.

The review also found that evidence about differentials across population groups and about what is driving the declines is limited. Possible explanations include changes in the demographic and socioeconomic composition of the older population, the prevalence and treatment of underlying chronic diseases, and the physical environment that facilitates daily

\section{Miss an issue of Population Briefs? Back issues are available free of charge while supplies last.}

\section{All issues of Population Briefs also are available on the Population Council's Web site: http://www.popcouncil.org/ publications/popbriefs/default.htm}

For a cumulative index:

http://www.popcouncil.org/publications/ popbriefs/pbindex.html

For more information or to order issues contact: Debra Warn, Office of Publications

Telephone: 212-339-0514

Fax: 212-755-6052

e-mail: dwarn@popcouncil.org activities. Without understanding the causes, it is difficult to predict future trends or to conclude that improved functioning means that future medical expenditures will be lower. Rather it could be that the improvements have been achieved as a result of past increases in health care costs.

\section{Growing older in Taiwan}

The Taiwan study focuses on changes in the prevalence of functional limitations among a nationally representative sample of adults aged 65 and older across the years 1993, 1996, and 1999. Using data from the Survey of Health and Living Status of the Elderly in Taiwan, the researchers looked at the ability to walk and climb stairs. These two tasks, which represent basic lower body movements, are less likely to be influenced by changes in living environments and social roles than are other activities, such as the ability to bathe, shop, or manage money.

The study showed that the prevalence of functional limitation increased between 1993 and 1996 and between 1996 and 1999. For example, in 1993, 25.5 percent of people 65 years and older had trouble walking or climbing stairs. By 1996, that figure had risen to 30.1 percent. In 1999, 35.7 percent of people in this age group had at least one of these limitations. Even after taking age, sex, education, ethnicity, and marital status into consideration, older adults in Taiwan were more likely to report limitations in 1999 than in 1993.

One possible reason that more older people appear to have limitations is the change in old-age survival in Taiwan. The country established its Universal Health Insurance program in 1995. The introduction of this plan is reported to have resulted in a rapid and dramatic increase in the use of both outpatient and inpatient care. Concurrently, Taiwan experienced an increase in life expectancy. "People with severe limitations may have been more likely to have died before the introduction of the Universal Health Insurance program," says Zimmer. "If people with severe disabilities were more likely to survive because of improved health care, then we would expect the prevalence of functional limitations to increase."

\section{Contradictory findings across populations?}

Comparing levels of functional limitations between Taiwan and the United States is difficult because of differences in questionnaire wording, survey techniques, and the ways in which individuals interpret health in different cultures and in different time periods. But it is not unreasonable that the trends are moving in opposite directions. Besides the recent change in availability of health care in Taiwan, economic development and public health programs have come much later to Taiwan than to the United States. Thus in comparison to older Americans, the elderly in Taiwan may have experienced substantially more difficult living and working environments and poorer health earlier in their lives, including greater exposure to infectious diseases with possible consequences later in life.

What the two populations do have in common is the likelihood that the elderly of tomorrow will be quite different from those of today. Many of these differences, such as greater educational attainment among more recent cohorts, may have positive implications for health. So even though the recent trend in late-life health is negative in Taiwan, Zimmer notes that "Young people in Taiwan are growing up under very different circumstances than did the older people now living in Taiwan. They are likely to enter their senior years much healthier than did their elders.'

\footnotetext{
SOURCES

Freedman, Vicki A., Linda G. Martin, and Robert F. Schoeni. 2002. "Recent trends in disability and functioning among older adults in the United States: A systematic review," Journal of the American Medical Association 288(24): 3137-3146.

Zimmer, Zachary, Linda G. Martin, and Ming-Cheng Chang. 2002. "Changes in functional limitation and survival among older Taiwanese, 1993, 1996, and 1999," Population Studies 56(3): 265-276. Expanded version published as Policy Research Division Working Paper no. 155. New York: Population Council.

OUTSIDE FUNDING

U.S. National Institute on Aging
} 


\section{RECENT PUBLICATIONS}

\section{Center for Biomedical Research}

Beaulieu, S., D.F. Robbiani, X. Du, E. Rodrigues, R. Ignatius, Y. Wei, P. Ponath, J.W. Young, M. PoPE, R.M. Steinman, and S. Mojsov. "Expression of a functional eotaxin (CC chemokine ligand 11) receptor CCR3 by human dendritic cells," Journal of Immunology 169(6): 2925-2936.

Blanchard, D.C., C.R. McKittrick, M.P. HARDY, and R.J. Blanchard. "Effects of social stress on hormones, brain, and behavior," in D.W. Pfaff, A.P. Arnold, A.M. Etgen, S.E. Fahrbach, and R.T. Rubin (eds.), Hormones, Brain, and Behavior, vol. 1. San Diego: Academic Press, pp. 735-763.

Chen, H., M.P. HARDY, and B.R. Zirkin. "Age-related decreases in Leydig cell testosterone production are not restored by exposure to LH in vitro," Endocrinology 143(5): 1637-1642.

Cheng, C.Y. and D.D. Mruk. "Cell junction dynamics in the testis: Sertoli-germ cell interactions and male contraceptive development," Physiological Reviews 82(4): 825-874.

Hu, J.H., X.B. He, Q. Wu, Y.C. Yan, and S.S. KoIDE. "Biphasic effect of GABA on rat sperm acrosome reaction: Involvement of $\mathrm{GABA}(\mathrm{A})$ and GABA(B) receptors," Archives of Andrology 48(5): 369-378.

Kenny, H.A., D.J. Bernard, T.H. Horton, and T.K. Woodruff. "Photoperiod-dependent regulation of inhibin in Siberian hamsters: I. Ovarian inhibin production and secretion," Journal of Endocrinology 174(1): 71-83.

“Photoperiod-dependent regulation of inhibin in Siberian hamsters: II. Regulation of inhibin production and secretion by pregnant mare serum gonadotropin," Journal of Endocrinology 174(1): 85-94.

Messmer, D., J. Bromberg, G. Devgan, J.-M. Jacqué, A. Granelli-Piperno, and M. PoPE. "Human immunodeficiency virus type 1 Nef mediates activation of STAT3 in immature dendritic cells," AIDS Research and Human Retroviruses 18(14): 1043-1050.

Ramachandra, S.G., V. Ramesh, H.N. Krishnamurthy, N. KUMAR, K. SUndARAM, M.P. HARDY, and A. Jagannadha Rao. "Effect of chronic administration of 7 -methyl-19-nortestosterone on serum testosterone, number of spermatozoa and fertility in adult male bonnet monkeys (Macaca radiata)," Reproduction 124(2): 301-309.

Sato, T., G.-M. Wang, M.P. HARDY, T. Kurita, G.R. Cunha, and P.S. Cooke. "Role of systemic and local IGF-I in the effects of estrogen on growth and epithelial proliferation of mouse uterus," Endocrinology 143(7): 2673-2679.
SCHLEGEL, P.N. and M.P. HARDY. "Male reproductive biology," in P.C. Walsh, A.B. Retik, E.D. Vaughan, Jr., A.J. Wein, L.R. Kavoussi, A.C. Novick, A.W. Partin, and C.A. Peters (eds.), Campbell's Urology, 8th Edition, vol. 2. Philadelphia: W.B. Saunders Company, pp. 1437-1474.

Shetty, G., G. Wilson, M.P. HARDY, E. Niu, I. Huhtaniemi, and M.L. Meistrich. "Inhibition of recovery of spermatogenesis in irradiated rats by different androgens," Endocrinology 143(9): 3385-3396.

Tash, J.A., S. McCallum, M.P. HARDY, B. Knudsen, and P.N. SCHLEGEL. "Men with nonobstructive azoospermia have Leydig cell hypertrophy but not hyperplasia," Journal of Urology 168(3): 1068-1070. Walch, L. and P.L. MorRIs. “Cyclooxygenase 2 pathway mediates IL-1 regulation of IL-1, -1 , and IL-6 mRNA levels in Leydig cell progenitors," Endocrinology 143(9): 3276-3283.

\section{International Programs Division}

Adeokun, Lawrence, Joanne E. Mantell, Eugene Weiss, Grace Ebun Delano, Temple Jagha, Jumoke Olatoregun, Dora Udo, Stella Akinso, and ELLEN WeISS. "Promoting dual protection in family planning clinics in Ibadan, Nigeria," International Family Planning Perspectives 28(2): 87-95.

Dadian, Margaret. “New study examines lives of MSM in Senegal," Global AIDS Link 72: 15.

Hargreaves, James R., Linda A. Morison, JANE Chege, Naomi Rutenberg, Maina Kahindo, Helen A. Weiss, Richard Hayes, and Anne Buvé for the Study Group on Heterogeneity of HIV Epidemics in African Cities. "Socioeconomic status and risk of HIV infection in an urban population in Kenya," Tropical Medicine and International Health 7(9): 793-802.

LANGeR, A. J. Villar, M. Romero, G. Nigenda, G. Piaggio, C. Kuchaisit, G. Rojas, M. Al-Osimi, J.M. Belizán, U. Farnot, Y. Al-Mazrou, G. Carroli, H. Ba'aqeel, P. Lumbiganon, A. Pinol, P. Bergsjö, L. Bakketeig, J. Garcia, and H. Berendes. "Are women and providers satisfied with antenatal care? Views on a standard and a simplified, evidence-based model of care in four developing countries," BMC Women's Health 2: 7.

Lien, Phan Thi, Christopher Elias, Nguyen Thi Loi, Bui Thi Chi, Nguyen Hua Phuc, and Michelle GARDNER. "The prevalence of reproductive tract infections in Hue, Vietnam," Studies in Family Planning 33(3): 217-226.

Maman, Suzanne, Jesie Mbwambo, Nora Hogan, Gad Kilonzo, Jacquelyn Campbell, ElLen WeISS, and Michael Sweat. "HIV-positive women report more lifetime partner violence: Findings from a voluntary counseling and testing clinic in Dar es Salaam, Tanzania," American Journal of Public Health 92(8): 1331-1337.
Pachauri, Saroj, Purnima Mane, and Sarah Hawkes (eds.). Sexual and Reproductive Health in South and Southeast Asia, special issue of Culture, Health \& Sexuality 4(2).

Rutenberg, Naomi. See Rutenberg et al. (Policy Research Division, Working Paper 162).

Sajan, Fatima and Fariyal F. Fikree. "Does early age at marriage influence gynaecological morbidities among Pakistani women?" Journal of Biosocial Science 34(3): 407-417.

Sathar, Zeba A. See Lloyd, Mete, and Sathar (Policy Research Division, Working Paper 164).

Working Papers, Policy Briefs

“CBD roles modified to address Zimbabwe's HIV/AIDS crisis," Frontiers OR Summary no. 29. Washington, DC: Population Council, www. popcouncil.org/pdfs/frontiers/orsummaries/ orsum29.pdf.

"Clarify goals and expand the reach of anti-trafficking programs," Frontiers OR Summary no. 28. Washington, DC: Population Council, www. popcouncil.org/pdfs/frontiers/orsummaries/ orsum28.pdf.

"Community sensitization must precede alternative coming-of-age rite," Frontiers OR Summary no. 27. Washington, DC: Population Council, www.popcouncil.org/pdfs/frontiers/ orsummaries/orsum27.pdf.

Creel, Liz C., Justine V. Sass, and Nancy V. Yinger. "Client-centered quality: Clients' perspectives and barriers to receiving care," New Perspectives on Quality of Care: No. 2.

Washington, DC: Population Council and Population Reference Bureau, www.popcouncil. org/pdfs/frontiers/00C/0OC-clients.pdf.

"Overview of quality of care in reproductive health: Definitions and measurements of quality," New Perspectives on Quality of Care: No. 1. Washington, DC: Population Council and Population Reference Bureau, www.popcouncil. org/pdfs/frontiers/00C/0OC-Overview.pdf

"Estimating the cost and effectiveness of different STI management strategies for sex workers in Madagascar," Horizons Research Summary. Washington, DC: Population Council.

"Greater involvement of PLHA in NGO service delivery: Findings from a four-country study," Horizons Research Summary. Washington, DC: Population Council.

Green, Cynthia P., Stephanie Joyce, and James R. ForeIT. "Using men as community-based distributors of condoms," Frontiers Program Brief No. 2 and Program Brief Summary No. 2. Washington, DC: Population Council, www.popcouncil.org/ pdfs/frontiers/pbriefs/male_CBDs_brf.pdf and www.popcouncil.org/pdfs/frontiers/pbriefs/ male_CBD_sum.pdf.

continued on page 8

Publications are by Population Council staff members and consultants. Year of publication is 2002 unless otherwise noted. Names in caps are staff members in the division. Interdivisional publications appear as full reference in first author's division and cross-reference in co-author's division. 


\section{continued from page 7}

Lantis, Kristina, Cynthia P. Green, and StePhanie JoYCE. "Providers and quality of care," New Perspectives on Quality of Care: No. 3. Washington, DC: Population Council and Population Reference Bureau, www.popcouncil. org/pdfs/frontiers/00C/ 00C-providers.pdf.

"Microfinance and households coping with HIV/AIDS in Zimbabwe: An exploratory study," Horizons Research Summary. Washington, DC: Population Council.

Murphy, Elaine M. “Best practices in clientprovider interactions in reproductive health services: A review of the literature." Washington, DC: Population Council, www.popcouncil.org/ pdfs/frontiers/00C/ 00C-LitReview.pdf.

\section{Reports}

Dadian, Margaret (ed.). Horizons Report: New Approaches to Sex Work and HIV/AIDS. Washington, DC: Population Council (available in English and Spanish).

Mishra, Anurag, Leila Caleb Varkey, Emma Ottolenghi, Anjana Das, Dale Huntington, and SUSAN ADAMCHAK. "Men in maternity study: Results from the pre-intervention survey of pregnant women and their husbands at three intervention and of only women at three control Employees' State Insurance Corporation dispensaries in Delhi, India," Frontiers report of preliminary findings. New Delhi: Population Council.

Niang, C.I., M. Diagne, Y. Niang, A.M. Moreau, D. Gomis, M. Diouf, K. Seck, A.S. Wade, P. TAPSOBA, and C. CASTLE. "Meeting the sexual health needs of men who have sex with men in Senegal," Horizons report. Washington, DC: Population Council.

Parker, Richard, Peter Aggleton, with Kathy Attawell, JULIE PULERWITZ, and Lisanne Brown. “HIV/AIDS-related stigma and discrimination: $A$ conceptual framework and an agenda for action," Horizons report. Washington, DC: Population Council.

Newsletters, Updates

Grupo de Trabajo sobre Derechos Sexuales y Reproductivos [Working group on sexual and reproductive rights]. "Desyres de la sexualidad: Violencia de género" [Gender violence], no. 9. Mexico City: Population Council, Fundación Mexicana para la Planeación Familiar, MEXFAM, Frente por el Fortalecimiento de la Cultura Laica, and the Interdisciplinary Program of Women Studies of El Colegio de México.

Mishra, Anurag, leila Caleb Varkey, Anjana Das, Emma Ottolenghi, Dale Huntington, Susan ADAMCHAK, and Shahina Begum. "Men in maternity study: A summary of the findings from preintervention interviews with women and their husbands attending antenatal clinics at ESIC facilities in Delhi," Frontiers Research Update. New Delhi: Population Council.

ROB, Ubaidur, Ismat BhuiYa, Nazia Yusuf, and Asiful Haider Chowdhury. "National HIV/AIDS database," Research Update no. 1. Dhaka: Population Council.

\section{Pamphlets}

Gomes, Victor. “Bank Ebar Factory-te." Dhaka: Population Council.

\section{Electronic Publications}

“Kenya PMCT Project-PMCT training curriculum: Prevention of mother-to-child transmission of HIV: A short course for health workers providing PMCT services in areas with limited resources and high HIV prevalence." Nairobi: Population Council (available in book or CD-ROM format).

Nicholaides, J. et al. Findings from the Field: $A$ Compilation to Date of Publications on HIV/AIDS from Horizons and Partner Organizations. Washington, DC: Population Council (available in CD-ROM format).

PulERWITZ, J. (ed.). Horizons AIDSQuest: The HIV/AIDS Survey Library (updated). www. popcouncil.org/horizons/AIDSQuest (also available in CD-ROM format).

\section{Policy Research Division}

BongaARTs, John. "Future population trends," in International Food Policy Research Institute, Sustainable Food Security for All by 2020: Proceedings of an International Conference, September 4-6, 2001, Bonn, Germany. Washington, DC: IFPRI.

- "The end of the fertility transition in the developed world," Population and Development Review 28(3): 419-443.

BongaARTS, JoHn and Zachary Zimmer. “Living arrangements of older adults in the developing world: An analysis of Demographic and Health Survey household surveys," Journals of Gerontology Series B: Psychological Sciences and Social Sciences 57(3): S145-S157.

ZIMMER, ZACHARY, Linda G. Martin, and MingCheng Chang. "Changes in functional limitation and survival among older Taiwanese, 1993, 1996, and 1999," Population Studies 56(3): 265-276.

\section{Working Papers}

162 Rutenberg, Naomi, Carol E. Kaufman, Kate Macintyre, Lisanne Brown, and Ali Karim. "Pregnant or positive: Adolescent childbearing and HIV risk in South Africa."

163 Mensch, Barbara S., Wesley H. Clark, and Dang Nguyen Anh. "Premarital sex in Vietnam: Is the current concern with adolescent reproductive health warranted?"

164 LLoYd, CYNTHiA B., Cem Mete, and Zeba A. Sathar. "The effect of gender differences in primary school access, type, and quality on the decision to enroll in rural Pakistan."

165 Hallman, Kelly, Agnes R. Quisumbing, Marie Ruel, and Bénédicte de la Brière. "Childcare, mothers' work, and earnings: Findings from the urban slums of Guatemala City."

166 Kaufman, Carol E. and Stavros E. Stavrou. “'Bus fare, please': The economics of sex and gifts among adolescents in urban South Africa."

167 Agyeman, Dominic K. and John B. CAsterline. "Social organization and reproductive behavior in southern Ghana."

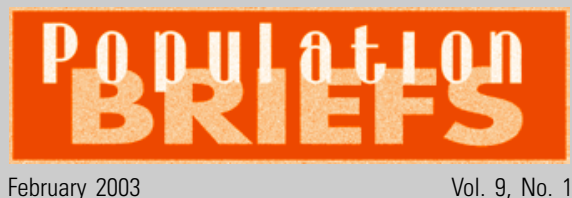

Population Briefs is a research newsletter of the Population Council. The Council is an international, nonprofit, nongovernmental organization that seeks to improve the wellbeing and reproductive health of current and future generations around the world and to help achieve a humane, equitable, and sustainable balance between people and resources. The Council conducts biomedical, social science, and public health research and helps build research capacities in developing countries. Established in 1952, the Counci is governed by an international board of trustees. Its New York headquarters supports a global network of regional and country offices.

Writer/Editor

Gina Duclayan

Editorial Board

Anrudh Jain, Cynthia B. Lloyd,

Melissa May, Irving Sivin

Production Manager

Y. Christina Tse

Production Artist

Sura Rosenthal

Copyeditor

Robert Heidel

Editorial Assistant

Jared Stamm

Circulation

Debra Warn

Population Briefs is distributed without charge. Information in this newsletter may be reproduced without permission, provided it is distributed without charge and the source is acknowledged.

\section{Y Y A R S
$1952-2002$
Population Council}

One Dag Hammarskjold Plaza

New York, NY 10017

fax: (212) 755-6052

e-mail: pubinfo@popcouncil.org

http://www.popcouncil.org

To receive e-mail when a new issue of Population Briefs is posted to the Population Council Web site, register at our Media Center: www.popcouncil.org/mediacenter/lists/default.html

ISSN 1084-6786

(C)2003 The Population Council, Inc.

Printed in the USA on recycled paper

\section{Other Council Publications}

Freedman, Vicki A., LINDA G. MARTIN, and Robert F. Schoeni. "Recent trends in disability and functioning among older adults in the United States: A systematic review," Journal of the American Medical Association 288(24): 3137-3146.

MARTIN, LINDA G. "Japan," in D.J. Ekerdt, R.A. Applebaum, K.C.A. Holden, S.G. Post, K. Rockwood, R. Schulz, R.L. Sprott, and P. Uhlenberg (eds.), Encyclopedia of Aging. New York: Macmillan Reference USA.

MARTIN, LINDA G. See Zimmer et al. (Policy Research Division).

Population Briefs 8(2)

Population and Development Review 28(3), 28(4)

Studies in Family Planning 33(3), 33(4) 